Aim of the study: One of the alternative methods of surgical treatment of vestibular schwannoma is Gamma Knife radiosurgery. The purpose of this metaanalysis was to analyze the progress in treatment of vestibular schwannoma using Gamma Knife radiosurgery based on data in the literature of the last five years.

Material and methods: In the collected English-language literature from the years 2007-2011, contained in 20 scientific journals, clinical articles of many years study at a single center were extracted and also review papers and case reports. The main criteria of our own analysis were: patient age, tumor size, the dose in Gy, the time from surgery to follow-up, the degree of tumor growth inhibition, and hearing preservation. For statistical calculations comparing series of studies we used nonparametric analysis of variance and tests at the significance level of $p>0.05$.

Results: The 46 evaluated clinical articles show the results of studies over many years. A comparison of the results of the analysis made on the basis of papers published in the period 1998-2007 with the results of the current series from the period 2007-2011 allowed us to establish that the average dose applied to the periphery of the tumor was lower (12.4 Gy) than in the earlier series of 1998-2007 (14.2 Gy), and hearing preservation was higher ( $66.45 \%$ vs. $51.0 \%)$.

Conclusions: Clinical findings widely documented in the literature over the past five years indicate the progress in treatment of vestibular schwannoma using Gamma Knife radiosurgery.

Key words: acoustic neuroma, Gamma Knife, hearing preservation, radiosurgery, vestibular schwannoma.

Contemp Oncol (Pozn) 2014; 18 (1): 60-66 DOI: $10.5114 /$ wo.2014.39840

\section{A meta-analysis of treatment of vestibular schwannoma using Gamma Knife radiosurgery}

\author{
Bartosz Rykaczewski ${ }^{1}$, Miroslaw Zabek $^{2}$
}

${ }^{1}$ Mazovia Regional Hospital, Warsaw, Poland

${ }^{2}$ Department of Neurosurgery, Postgraduate Medical Center, Brodno Mazovia Hospital, Warsaw, Poland

\section{Introduction}

Vestibular schwannoma (VS), also called acoustic neuroma, is a benign tumor arising from Schwann cells of the vestibular portion of the eighth cranial nerve inside the internal auditory canal. With tumor growth it fills the internal auditory canal and extends beyond it, reaching the cerebellopontine angle region. The most common symptoms of VS occurrence are progressive deterioration of hearing, dizziness and headache. The progression of the tumor to nerve $V$ leads to facial paresthesia. When the tumor reaches nerves $I X, X$, and $X \mid$ there are difficulties in swallowing. Compression of the brain stem by the tumor leads to an imbalance and sometimes hydrocephalus. The incidence of these tumors is estimated at one in 100000 people a year, but recently in connection with the frequent use of magnetic resonance imaging (MRI) detection of VS is twice as high [1,2].

One of the alternative methods of surgical treatment of VS is Gamma Knife radiosurgery (GKRS). Clinical experience with proton beam irradiation to the central part of the brain was initiated in the 1960s by Professor Lars Lexell at the Gustaf Werner Institute in Uppsala (Sweden) [3]. In 1967, when this therapeutic tool was used for the first time, the name "Gamma Knife" (GK) was coined. The basic concept of GK was that extremely well-collimated beams from a large number of Cobalt-60 sources, distributed around a half-spherical collimator helmet, would allow a circumscribed focus of beam to be produced in the central part of the patient's skull. The initial goal was to offer the use of GK surgery, the traditional non-surgical removal of only some of the lesions, but later it was found that precise irradiation of small intracranial tumors located even in the pituitary gland was possible. Currently, the number of patients treated using the Gamma Knife is estimated at 50000 a year [4].

Worldwide, there are four models using the Gamma Knife: U/A, B, C/4-C and LGK Perfexion $[5,6]$. The last model was introduced in 2006. It allows the range of operation to be extended and is equipped with advanced dose planning software, for precise and dynamic beam shaping.

Based on a population of 40000000 in Poland it is estimated that about 500 vestibular schwannomas are newly diagnosed each year and most of them are treated by a retrosigmoid approach in general anesthesia in neurosurgery departments. In Poland, the Leksell Gamma Knife Perfexion was installed in 2010 in only one center in Warsaw. To date it has been used for the operation of 320 patients with VS. Due to the relatively short time that has elapsed since the application of GK, there are no data about the effects of this method of treatment over time. The purpose of this study was to analyze the progress in treatment of vestibular schwannoma using Gamma Knife radiosurgery based on data in the literature from the last five years. 


\section{Material and methods}

Articles published in 2007-2011 were searched using PubMed and Medline search engines and publishers Springer, Elsevier and Kluwer, the database in English, using the keywords "gamma knife", "vestibular schwannoma" and "acoustic neuroma". With over 700 abstracts, to continue the search full texts of the various items of literature that contain all the keywords "gamma knife" and "vestibular schwannoma" and "gamma knife" and "acoustic neuroma" were selected. The collected material, located in 20 scientific journals, comprised case studies, analyses of the work of many years of study at a single center, and review papers. Interesting was the use of new models of Leksell Gamma Knife in the various medical centers. The main criteria for the analysis were patient age, tumor size, dose (Gy), the period from radiosurgery to control, the degree of inhibition of tumor growth, and hearing preservation. Correlations between the investigated characteristics were determined using Microsoft Excel. For statistical calculations comparing the series, nonparametric analysis of variance was used and the following tests: Kruskal-Wallis, Van der Waerden, Kolmogorov-Smirnov test, and median one-way analysis. The level of significance was $p<0.05$.

\section{Results}

In total, 46 long-term clinical studies covering a period from 3 to 22 years were included [7-52] (Table 1). The longest observations took place in the following medical centers: Pittsburgh (USA), Marseille (France), Komaki (Japan) and Seoul (Korea). The works used different models of Gamma Knife, depending on the period of study and institutions. The latest model, PFX Leksell Gamma Knife, was used in studies at the University of Verona [34] and Marseille [42], and the 4-C model in the study at the University of Pittsburgh [12, 17, 25, 35], Nijmegen [31, 41], Philadelphia [43] and Maastricht [46, 47].

For further analysis the literature was selected according to data required for the analysis of own studies (Table 2). The total number of patients meeting the criteria for the work selected in 28 articles was 3233 [7, 9, 12, 15-17, 22, 23, 25-27, 29, 30, 33, 34, 36-41, 43, 45, 47-50, 52]. The described groups of patients ranged from 21 to 444 in size depending on location and duration of the study [33, 36]. Average age was 52.6 years. The lowest was 29 , and the highest was 68 years $[40,38]$. Tumor volume varied from 0.17 to $12.6 \mathrm{~cm}^{3}$ and on average was $3.9 \mathrm{~cm}^{3}$. The Gamma Knife surgery (GKS) radiation dose to the periphery of the tumor was on average $12.4 \mathrm{~Gy}$, but was greater than 13.0 Gy only in one publication [12]. The resulting tumor growth control was achieved in $92.7 \%$, and the preservation of serviceable hearing was on average $66.45 \%$ with a mean follow-up of 51.24 months. There was no significant correlation between radiation dose and GKS tumor growth inhibition and hearing preservation. In the overall analysis case studies are not included due to the small database [53-58].

The efficacy of radiosurgery using the Gamma Knife in the comprehensive analysis of data from 28 papers
(Table 2) was compared with several meta-analyses contained in the scientific literature [1, 59-66] (Table 3). Age of patients ranged on average from 51.8 to 57 years $[64,60]$. Tumor size presented in units of volume ranged from 2.7 to $4.0 \mathrm{~cm}^{3}$. With an observation period from 16 to over 60 months, tumor growth inhibition was achieved in an average of 81 to $100 \%$ of patients, and the preservation of serviceable hearing from 20 to $57 \%$ of such patients.

A comparison of the results of the analysis made on the basis of papers published in the period 1998-2007 [64] with the analysis of the current series of works from the period 2007-2011 shows that both of these series combine the highest similarity in the type of data obtained. Based on surveys, it was found that data on patient age, tumor size and tumor growth control are not significantly different between the several sets of analyses (Table 4). There was, however, a highly significant difference in the size of the dose and in the degree of serviceable hearing preservation, and quite significant in the follow-up (Fig. 1, 2 and 3). In the current series of studies, the dose applied to the periphery of the tumor was lower, the hearing preservation was higher, and the follow-up was longer than in previous series [64].

\section{Discussion}

The most important goal in treating patients with vestibular schwannoma is the control of tumor growth and maintaining the quality of life $(\mathrm{QOL})$, while minimizing the side effects of treatment. Gamma Knife generally meets these criteria and is used successfully worldwide as an alternative method of treatment of VS [50]. The use of the Gamma Knife in radiosurgery of vestibular schwannoma is a breakthrough for patients suffering from this disease. In most cases, it does not create a need for hospitalization $[63,64]$. The results of many years of experience, gained in leading medical institutions, have led to improvements of GK $[5,6]$. The latest model, LGK PFX, is more widely used, most recently in Russia and Ukraine [4]. Implementation of a quantitative comparison of radiosurgical treatment of VSs using the Leksell Gamma Knife Perfexion and Model $C$ has shown that the most important new features of PFX lead to improvement of dosimetric parameters, especially for large tumors [42]. Optimizing the dose planning can improve results of treatment, but a fully comprehensive assessment of the benefits to patients requires long-term clinical observations.

In numerous studies on the use of Gamma Knife radiosurgery for vestibular schwannomas, there are many factors that have been frequently studied in detail [7-52]. These include patient age, tumor size, dose to the tumor periphery, tumor growth control, the preservation of hearing and facial nerve function, and the quality of life after radiosurgery. To analyze the preservation of hearing, most neuro-laryngology reports use the classification of AAOHNS and the majority of neurosurgical publications apply the GR classification [17]. Differences between pre- and postoperative hearing class are presented differently in each survey. A common strategy is, however, the use of the concept of serviceable hearing (GR grade I or II or the 
Table 1. Institution, years of clinical studies and the model of Gamma Knife

\begin{tabular}{|c|c|c|c|}
\hline First author, year & Institution* & Years of the study & Model of GK** \\
\hline Chopra, 2007 & University of Pittsburgh, USA & $1992-2000$ & B, C, U \\
\hline Iwai, 2007 & Osaka City General Hospital, Japaan & 1994-2004 & DN \\
\hline Kim, 2007 & Seoul National University, Korea & 1997-2001 & DN \\
\hline Litre, 2007 & Timone University, Marseille, France & 1992-2003 & DN \\
\hline Massager, 2007 & University of Brussels, Belgium & 2000-2004 & C \\
\hline Mathieu, 2007 & University of Pittsburgh, USA & 1987-2005 & U, B, C, 4-C \\
\hline Delsanti, 2008 & Gamma Knife Center, Marseille, France & 1992-2004 & DN \\
\hline Dewan, 2008 & Brown University, USA & 1994-2007 & DN \\
\hline Iwai, 2008 & Osaka City General Hospital, Japan & 1994-2003 & DN \\
\hline Nagano, 2008 & Chiba University, Japan & 1998-2006 & DN \\
\hline Niranjan, 2008 & University of Pittsburgh, USA & 1987-2003 & B, C, 4-C \\
\hline Lasak, 2008 & Kansas University, USA & 2003-2007 & C \\
\hline Shuto, 2008 & Yokohama Rosai Hospital, Japan & 1992-2005 & B \\
\hline Wackym, 2008 & Medical College of Wisconsin, USA & 2000-2008 & B \\
\hline Yang, 2008 & University Hospital of Goyang, Korea & 1998-2004 & $B, C$ \\
\hline Franzin, 2009 & IRCCS San Raffaele, Italy & 2001-2007 & C \\
\hline Fukuoka, 2009 & Hospital of Sapporo, Japan & 1991-2003 & $\mathrm{DN}$ \\
\hline Ganz, 2009 & Nasser Institute Shobra, Egypt & DN & DN \\
\hline Kano, 2009 & University of Pittsburgh, USA & 2004-2007 & C, $4-C$ \\
\hline Liscak, 2009 & Na Homolce Hospital, Prague, Czech Republic & 1992-2001 & B \\
\hline Lobato-Polo, 2009 & University of Pittsburgh, USA & 1987-2003 & U, B, C, \\
\hline Myrseth, 2009 & Haukeland University Hospital, Norway & 2001-2006 & C \\
\hline Pollock, 2009 & Mayo Clinic, Rochester, USA & 1990-2004 & DN \\
\hline Tamura, 2009 & Timone University, Marseille, France & $1992-2003$ & $\mathrm{~B}, \mathrm{C}$ \\
\hline Timmer, 2009 & Radbout University, Nijmegen, The Netherlands & 2003-2007 & $4-C$ \\
\hline Yomo, 2009 & Timone University, Marseille, France & 1992-2007 & $\mathrm{B}, \mathrm{C}$ \\
\hline Chung, 2010 & Taipei Veterans General Hospital, Taiwan & 1993-2009 & $\mathrm{B}, \mathrm{C}$ \\
\hline Gerosa, 2010 & University of Verona, Italy & 2003-2009 & C, PFX \\
\hline Kano, 2010 & University of Pittsburgh, USA & 1987-2008 & $U, B, C, 4-C$ \\
\hline Lee, 2010 & Taipei Veterans General Hospital, Taiwan & $1993-2008$ & $B, C$ \\
\hline Nagano, 2010 & Chiba Center, Tokyo, Japan & $1998-2004$ & $B, C$ \\
\hline Nakaya, 2010 & University of Pittsburg, USA & 1987-1991 & $U, B, C$ \\
\hline Regis, 2010 & Timone University, Marseille, France & 1981-1999 & B \\
\hline Sharma, 2010 & All India Medical Institute, India & 1997-2008 & B \\
\hline Timmer, 2010 & Radbout University, Nijmegen, The Netherlands & $2003-2007$ & $4-C$ \\
\hline Yomo, 2010 & Timone University, Marseille, France & 2006-2008 & 4-C, PFX \\
\hline Brown, 2011 & University of Pennsylvania, USA & 2006-2009 & $4-C$ \\
\hline Haque, 2011 & Columbia University, New York, USA & 1998-2009 & $\mathrm{DN}$ \\
\hline Hasegawa, 2011 & Komaki City Hospital, Japan & 1991-2009 & $\mathrm{DN}$ \\
\hline Langenberg, 2011a & Maastricht University, The Netherlands & 2002-2009 & $4-C$ \\
\hline Langenberg, 2011b & Maastricht University, The Netherlands & 2002-2009 & $4-\mathrm{C}$ \\
\hline Massager, 2011 & Gamma Knife Center, Brussels, Belgium & DN & C \\
\hline Milligan, 2011 & Mayo Clinic, Rochester, USA & 1997-2006 & DN \\
\hline Murphy, 2011a & Cleveland Clinic, USA & 1997-2003 & $\mathrm{B}, \mathrm{C}$ \\
\hline Park, 2011 & Kyung University of Seoul, Korea & 1994-2009 & DN \\
\hline Yang, 2011 & University of Pittsburgh, USA & 1994-2008 & DN \\
\hline
\end{tabular}

* short name

**eksell Gamma Knife, Elekta Instruments, Stockholm, Sweden

DN - data not available 
Table 2. Data summary from papers listed

\begin{tabular}{|c|c|c|c|c|c|c|c|}
\hline First author, year & $\begin{array}{l}\text { Number } \\
\text { of patients }\end{array}$ & $\begin{array}{l}\text { Age } \\
\text { (yrs) }\end{array}$ & $\begin{array}{l}\text { Tumor } \\
\text { volume } \\
\left(\mathrm{cm}^{3}\right)\end{array}$ & $\begin{array}{l}\text { Margin } \\
\text { dose (Gy) }\end{array}$ & $\begin{array}{l}\text { Mean } \\
\text { follow-up } \\
\text { (months) }\end{array}$ & $\begin{array}{l}\text { Tumor } \\
\text { control (\%) }\end{array}$ & $\begin{array}{l}\text { Hearing } \\
\text { preservation } \\
(\%)^{*}\end{array}$ \\
\hline Chopra, 2007 & 216 & 56.5 & 1.3 & 13 & 68 & 98.3 & 70.0 \\
\hline Kim, 2007 & 59 & 48 & 3.41 & 12 & 73 & 97 & 33.3 \\
\hline Mathieu, 2007 & 62 & 36 & 5.7 & 14.0 & 53 & 85 & 48 \\
\hline Iwai, 2008 & 25 & 48 & 0.27 & 12 & 89 & 96 & 64 \\
\hline Nagano, 2008 & 100 & 59.1 & 2.7 & 12.2 & 66 & 91 & 60 \\
\hline Niranjan, 2008 & 96 & 54 & 1.12 & 13 & 28 & 99 & 77.5 \\
\hline Franzin, 2009 & 50 & 54 & 0.73 & 13 & 36 & 96 & 68 \\
\hline Fukuoka, 2009 & 152 & 54 & 2.0 & 12 & 60 & 94 & 71 \\
\hline Kano, 2009 & 77 & 52 & 0.75 & 12.5 & 20 & 94.7 & 71 \\
\hline Liscak, 2009 & 351 & 56 & 1.9 & 12.5 & 43 & 91 & 50 \\
\hline Lobato-Polo, 2009 & 55 & 35 & 0.17 & 13 & 64 & 96 & 93 \\
\hline Pollock, 2009 & 293 & 58 & & 13 & 84 & 94 & \\
\hline Tamura, 2009 & 74 & 47.5 & 1.35 & 12 & 48 & 93 & 78.4 \\
\hline Chung, 2010 & 21 & 49.5 & 17.3 & 11.9 & 66 & 90.5 & \\
\hline Gerosa, 2010 & 74 & 59 & 2.7 & 12.4 & 50 & 96 & 72 \\
\hline Lee, 2010 & 444 & 51.0 & 4.4 & 12.0 & 35.7 & 79.1 & \\
\hline Nagano, 2010 & 87 & 58.6 & 2.5 & 12.0 & 90 & 89.7 & \\
\hline Nakaya, 2010 & 202 & 68 & 3.9 & 13 & 65 & 97 & 79 \\
\hline Regis, 2010 & 47 & 54.4 & 11.2 & & 34.7 & 97 & 79 \\
\hline Sharma, 2010 & 30 & 29 & 3.7 & 12.0 & 26.6 & 87.5 & 66.7 \\
\hline Timmer, 2010 & 108 & 56 & 2.721 & 11.1 & & & 78 \\
\hline Brown, 2011 & 53 & 56 & 1. 12 & 12.5 & 16 & 96 & 79 \\
\hline Hasegawa, 2011 & 117 & 52 & 1.9 & 12 & 56 & 97.5 & 43 \\
\hline Langenberg, 2011b & 33 & 54.8 & 8.8 & 12.6 & 30.0 & 88 & 58 \\
\hline Massager, 2011 & 203 & 53 & & 12 & 42 & 89.7 & 41.8 \\
\hline Milligan, 2011 & 22 & 61.0 & 9.4 & 12 & 66 & 86 & 47 \\
\hline Murphy, 2011a & 117 & 60.9 & 1.95 & 12.8 & 37.5 & 91.8 & 85 \\
\hline Yang, 2011 & 65 & 51 & 9 & & 36 & 93 & 82 \\
\hline Total & 3233 & & & & & & \\
\hline Mean & & 52.6 & 3.90 & 12.40 & 51.24 & 92.73 & 66.45 \\
\hline
\end{tabular}

Empty data fields are from data that were not reported, not accessible, or could not be disaggregated for analysis in this study.

*Hearing preservation in grade I-II according to Gardner-Robertson scale (good-serviceable, pure tone average 0-50 dB, speech discrimination 50-100\%)

AAO-HNS class A or B). Such a strategy was adopted in this work.

The results of a systematic study by Yang and colleagues show that the radiation dose is an important and critical prognostic factor for hearing preservation regardless of tumor size or age of patients with VS treated with GKRS [63]. Patients treated with doses $\leq 13$ Gy had better hearing compared to patients treated with high doses. Results of treatment of hearing loss in older patients were comparable to the results of younger patients. Similarly, patients with large tumors had clinical indicators of serviceable hearing loss compared to patients with small tumors. This suggests that patient age and tumor size may not be critical prognostic factors in predicting the preservation of hearing after GKRS. The analysis presented in this study, conducted on the basis of the results documented in the literature of the last five years, points to the patients' age and tumor size being less critical in predicting preservation of hearing. Highly important, however, was the application of the lower radiation dose to the periphery of the tumor used in recent years, thanks to the introduction into medical centers of the new models of GK and greater possibilities of precise planning.

The results of a comprehensive analysis of facial nerve preservation after radiosurgery of VS using GK confirmed the importance of medium doses of radiation as an important and critical prognostic factor [62]. In this case, however, the patient's age played a significant role. In patients treated with 13 Gy or less, with tumors smaller than $1.5 \mathrm{~cm}^{3}$ in volume, results of treatment in young pa- 
Table 3. Data from review papers

\begin{tabular}{|c|c|c|c|c|c|c|c|c|}
\hline $\begin{array}{l}\text { First author, year } \\
\text { [references] }\end{array}$ & $\begin{array}{l}\text { Years } \\
\text { of cited } \\
\text { publications }\end{array}$ & $\begin{array}{l}\text { Number of } \\
\text { patients }\end{array}$ & $\begin{array}{l}\text { Age of } \\
\text { patients }\end{array}$ & $\begin{array}{l}\text { Tumor } \\
\text { volume } \\
\left(\mathrm{cm}^{3}\right)\end{array}$ & $\begin{array}{l}\text { Marginal } \\
\text { dose (Gy) }\end{array}$ & $\begin{array}{l}\text { Mean } \\
\text { follow-up } \\
\text { (months) }\end{array}$ & $\begin{array}{l}\text { Tumor } \\
\text { control (\%) }\end{array}$ & $\begin{array}{l}\text { Hearing } \\
\text { preser- } \\
\text { vation (\%) }\end{array}$ \\
\hline Myrseth, 2007 [37] & 1989-2006 & 300 & & & & & & \\
\hline Rowe, 2007 [50] & $1984-2005$ & 856 & 57 & 2.8 & 13.0 & 45.0 & & \\
\hline Sughrue, 2009 [53] & 1979-2007 & 50000 & & $<25 \mathrm{~mm}$ & $>13 ;<13$ & & & \\
\hline Yang, 2009 [62] & 1990-2007 & 1908 & 55.3 & 3.2 & 13.1 & 54.1 & 82.5 & \\
\hline Yang, 2009 [61] & 1988-2007 & 2083 & 53.6 & 4.05 & 16 & 41.2 & 94 & 57 \\
\hline Yang, 2010 [63] & 1998-2007 & 4234 & 51.8 & 3.9 & 14.2 & 44.4 & 92.0 & 51.0 \\
\hline Arthurs, 2011 [2] & 2004-2009 & $397-5825$ & & $2.7-4.0$ & $13.7-17.3$ & $25-60$ & $91-94.6$ & $44-57$ \\
\hline Murphy, 2011 [36] & $1992-2010$ & $29-162$ & & $<3-3.14$ & $8-25$ & $16->60$ & $81-100$ & $20-51$ \\
\hline Whitmore, 2011 [59] & 1990-2008 & & & & & & & \\
\hline
\end{tabular}

Empty data fields are from data that were not reported.

Table 4. Comparison of data from earlier studies [63] and current series - results of variance analysis - $p$-value*

\begin{tabular}{llllllll}
\hline Kind of statistical test & $\begin{array}{l}\text { Number of } \\
\text { patients }\end{array}$ & $\begin{array}{l}\text { Age of } \\
\text { patients }\end{array}$ & $\begin{array}{l}\text { Tumor } \\
\text { volume }\end{array}$ & $\begin{array}{l}\text { Marginal } \\
\text { dose (Gy) }\end{array}$ & Follow-up & $\begin{array}{l}\text { Tumor control } \\
\text { rate }\end{array}$ & $\begin{array}{l}\text { Hearing } \\
\text { preservation }\end{array}$ \\
$\begin{array}{l}\text { Kruskal-Wallis Test } \\
\text { Pr }>\chi^{2}\end{array}$ & 0.2480 & 0.5462 & 0.3461 & $\mathbf{0 . 0 0 0 9}$ & $\mathbf{0 . 0 3 9 8}$ & 0.2614 & $\mathbf{0 . 0 1 6 6}$ \\
$\begin{array}{l}\text { Median One-Way Analysis } \\
\text { Pr }>\chi^{2}\end{array}$ & 0.3369 & 0.1662 & 0.1055 & $\mathbf{0 . 0 0 0 6}$ & 0.0906 & 0.7078 & $\mathbf{0 . 0 1 5 7}$ \\
$\begin{array}{l}\text { Van der Waerden One-Way Analysis } \\
\text { Pr }>\chi^{2}\end{array}$ & 0.1980 & 0.5976 & 0.4688 & $\mathbf{0 . 0 0 1 0}$ & 0.0736 & 0.2099 & $\mathbf{0 . 0 2 5 9}$ \\
$\begin{array}{l}\text { Kolmogorov-Smirnov } \\
\text { Two-Sample Test Pr }>\text { KSa }\end{array}$ & 0.4509 & 0.7154 & 0.1312 & $\mathbf{0 . 0 0 8 6}$ & 0.0889 & 0.6079 & $\mathbf{0 . 0 3 8 2}$
\end{tabular}

* Significance at $p<0.05$

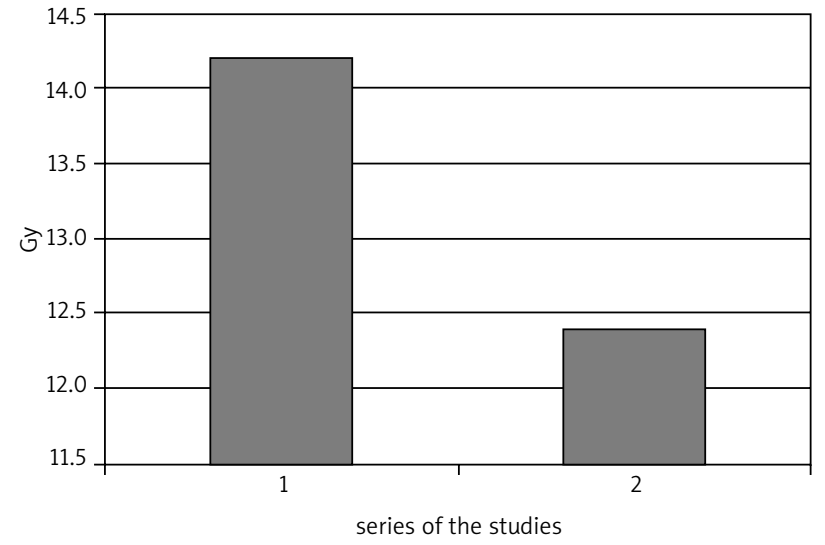

Fig. 1. Marginal dose in the earlier (1) [63] and current (2) series of studies - significance of differentiation in Table 4

tients were better than in older patients. According to Kim et al. [6] to reduce the radiation dose, however, does not adequately protect the hearing, and therefore it is believed that this is a more complicated problem and requires further study. Common hypotheses for hearing deterioration after irradiation include damage to cochlear primary sensory cells, injury to the cochlear nerve by the tumor, injury to the cochlear nerve by radiation, and compression or vascular thrombosis, leading to ischemic injury of the

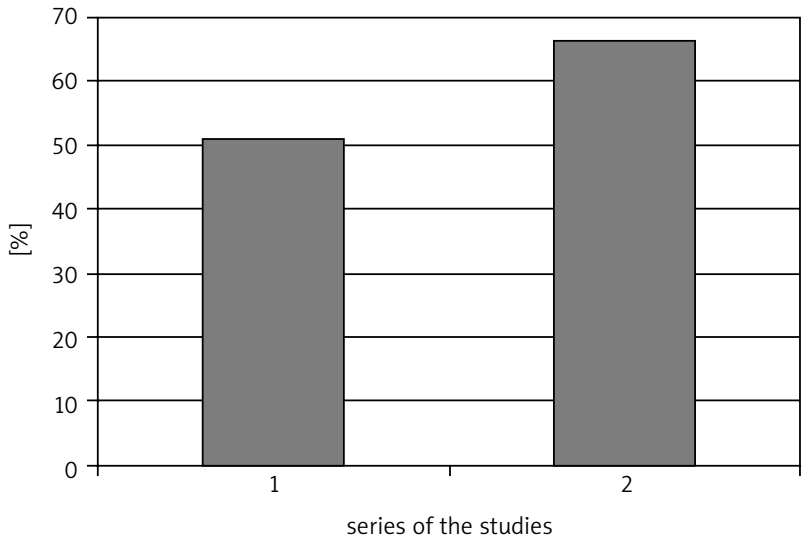

Fig. 2. Hearing preservation in the earlier (1) [63] and current (2) series of studies - significance of differentiation in Table 4

cochlea [25]. Franzin [22] believes that due to the high frequency of hearing loss in patients prior to radiosurgery, it is difficult to determine whether hearing loss is caused by the surgery or the natural course of the disease. The exact mechanism of delayed hearing loss is still unclear.

Preservation of hearing in patients is associated with the overall quality of life (QOL). Whitmore et al. [65] compared the quality of life in patients after 5 years of radiosurgical and surgical treatment. Overall QOL was better 


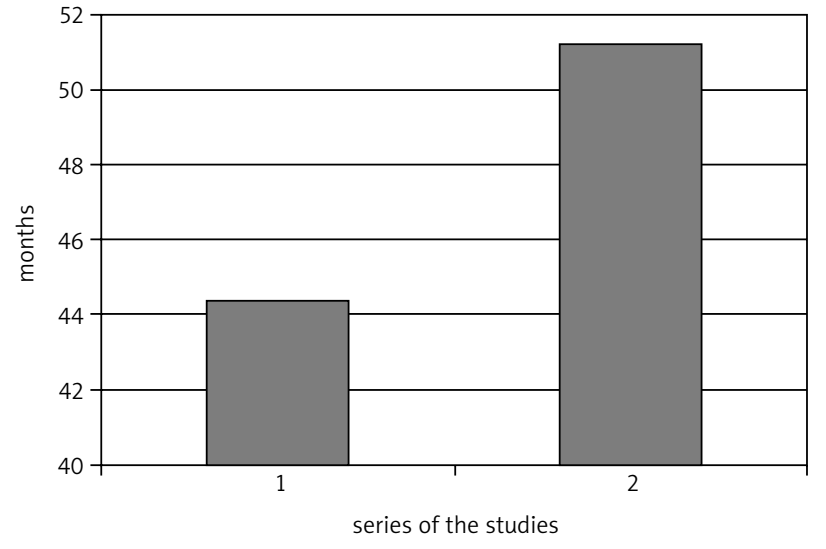

Fig. 3. Follow-up in the earlier (1) [63] and current (2) series of studies - significance of differentiation in Table 4

when patients were treated with radiosurgery, but too little information on QOL after 10 years did not allow this thesis to be proved in the long run. There is a need for further research in this field [59].

In conclusion, clinical findings widely documented in the literature over the past five years indicate the progress in treatment of vestibular schwannoma using Gamma Knife radiosurgery. In a new series of studies, published in 2007-2011, the average dose applied to the periphery of the tumor was lower (12.4 Gy) than in the earlier series from the years 1998 to 2007 (14.2 Gy), and hearing preservation was higher (66.45\% vs. $51.0 \%)$. This was confirmed statistically, and the differences were highly significant.

\section{Authors declare no conflict of interest.}

\section{References}

1. Arthurs BJ, Fairbanks RK, Demakas JJ, et al: A review of treatment modalities for vestibular schwannoma. Neurosurg Rev 2011; 34: 265-79.

2. Fortnum H, O'Neill C, Taylor R, et al. The role of magnetic resonance imaging in the identification of suspected acoustic neuroma: a systematic review of clinical and cost effectiveness and natural history. Health Technol Assess 2009; 13: iii-iv, ix-xi, 1-154.

3. Backlund EO. Gamma knife - the early story: memoires of a privileged man. In: Radiosurgery and Pathological Fundamentals. Prog Neurol Surg 2007; 20: XXI-XXIII.

4. Elekta Instruments, Sztokholm (electa.org.)

5. Niranjan A, Maitz AH, Lunsford A, Gerszten PC, Flickinger JC, Kondziolka D, Lunsford LD. Radiosurgery techniques and current devices. Prog Neurol Surg 2007; 20: 50-67.

6. Régis J, Roche PH, Delsanti C, Thomassin JM, Ouaknine M, Gabert K, Pellet W. Modern management of vestibular schwannomas. Prog Neurol Surg 2007; 20: 129-41.

7. Chopra R, Kondziolka D, Niranjan A, Lunsford LD, Flickinger JC. Long-term follow-up of acoustic schwannoma radiosurgery with marginal tumor doses of 12 to 13 Gy. Int I Radiat Oncol Biol Phys 2007; 68: 845-51.

8. Iwai Y, Yamanaka K, Yamagata K, Yasui T. Surgery after radiosur gery for acoustic neuromas: Surgical strategy and histological findings. Neurosurgery 2007; 60 (2 Suppl 1): ONS75-82

9. Kim KM, Park CK, Chung HT, Paek SH, Jung HW, Kim DG. Long-term outcomes of gamma knife stereotactic radiosurgery of vestibular schwannomas. J Korean Neurosurg Soc 2007; 42: 286-92.
10. Litre CF, Gourg GP, Tamura M, Mdarhri D, Touzani A, Roche PH, Régis J. Gamma Knife surgery for facial nerve schwannomas. Neurosurgery 2007; 60: 853-9.

11. Massager N, Nissim O, Delbrouck C, et al. Irradiation of cochlear structures during vestibular schwannoma radiosurgery and associated hearing outcome. J Neurosurg 2007; 107: 733-9.

12. Mathieu D, Kondziolka D, Flickinger JC, Niranjan A, Williamson R, Martin JJ, Lunsford LD. Stereotactic radiosurgery for vestibular schwannomas in patients with neurofibromatosis type 2: an analysis of tumor control, complications, and hearing preservation rates. Neurosurgery 2007; 60: 460-8.

13. Delsanti C, Roche PH, Thomassin JM, Régis J. Morphological changes of vestibular schwannomas after radiosurgical treatment: pitfalls and diagnosis of failure. Prog Neurol Surg 2008; 21: 93-7.

14. Dewan S, Norén G. Retreatment of vestibular schwannomas with Gamma Knife surgery. J Neurosurg 2008; 109 Suppl: 144-8.

15. Iwai Y, Yamanaka K, Kubo T, Aiba T. Gamma knife radiosurgery for intracanalicular acoustic neuromas. J Clin Neurosci 2008; 15: 993-7.

16. Nagano O, Higuchi Y, Serizawa T, Ono J, Matsuda S, Yamakami I, Saeki N. Transient expansion of vestibular schwannoma following stereotactic radiosurgery. J Neurosurg 2008; 109: 811-6.

17. Niranjan A, Mathieu D, Flickinger JC, Kondziolka D, Lunsford LD. Hearing preservation after intracanalicular vestibular schwannoma radiosurgery. Neurosurgery 2008; 63: 1054-62.

18. Lasak JM, Klish D, Kryzer TC, Hearn C, Gorecki JP, Rine GP. Gamma Knife radiosurgery for vestibular schwannoma: early hearing outcomes and evaluation of the cochlear dose. Otol Neurotol 2008; 29: 1179-86.

19. Shuto T, Inomori S, Matsunaga S, Fujino H. Microsurgery for vestibular schwannoma after Gamma Knife radiosurgery. Acta Neurochir (Wien) 2008; 150: 229-34.

20. Wackym PA, Hannley MT, Runge-Samuelson CL, Jensen J, Zhu YR Gamma Knife surgery of vestibular schwannomas: longitudinal changes in vestibular function and measurement of the Dizziness Handicap Inventory. J Neurosurg 2008; 109 Suppl: 137-43.

21. Yang SY, Kim DG, Chung HT, Park SH, Paek SH, Jung HW. Evaluation of tumour response after gamma knife radiosurgery for residual vestibular schwannomas based on MRI morphological features. J Neurol Neurosurg Psychiatry 2008; 79: 431-6.

22. Franzin A, Spatola G, Serra C, Picozzi P, Medone M, Milani D, Castellazzi P, Mortini P. Evaluation of hearing function after Gamma Knife surgery of vestibular schwannomas. Neurosurg Focus 2009; 27: E3.

23. Fukuoka S, Takanashi M, Hojyo A, Konishi M, Tanaka C, Nakamura H. Gamma knife radiosurgery for vestibular schwannomas. Prog Neurol Surg 2009; 22: 45-62.

24. Ganz JC, Reda WA, Abdelkarim K. Adverse radiation effects after Gamma Knife Surgery in relation to dose and volume. Acta Neurochir 2009; 151: 9-19.

25. Kano H, Kondziolka D, Khan A, Flickinger JC, Lunsford LD. Predictors of hearing preservation after stereotactic radiosurgery for acoustic neuroma. J Neurosurg 2009; 111: 863-73.

26. Liscak R, Vladyka V, Urgosik D, Simonova G, Vymazal J. Repeated treatment of vestibular schwannomas after Gamma Knife radiosurgery. Acta Neurochir 2009; 151: 317-24.

27. Lobato-Polo J, Kondziolka D, Zorro O, Kano H, Flickinger JC, Lunsford LD. Gamma Knife radiosurgery in younger patients with vestibular schwannomas. Neurosurgery 2009; 65: 294-301.

28. Myrseth E, M ller P, Pedersen PH, Lund-Johansen M. Vestibular schwannoma: surgery or Gamma Knife radiosurgery ? A perspective, nonrandomized study. Neurosurgery 2009; 64: 654-63.

29. Pollock BE, Link MJ, Foote RL. Failure rate of contemporary lowdose radiosurgical technique for vestibular schwannoma. I Neurosurg 2009; 111: 840-4.

30. Tamura M, Carron R, Yomo S, et al. Hearing preservation after gamma knife radiosurgery for vestibular schwannomas presenting with high-level hearing. Neurosurgery 2009; 64: 289-96.

31. Timmer FC, Hanssens PE, van Haren AE, Mulder JJ, Cremers CW, Beynon AJ, van Overbeeke JJ, Graamans K. Gamma Knife radiosurgery for vestibular schwannomas: results of hearing preservation in relation to the cochlear radiation dose. Laryngoscope 2009; 119: 1076-81. 
32. Yomo S, Arkha Y, Delsanti C, Roche PH, Thomassin JM, Régis J. Repeat Gamma Knife surgery for regrowth of vestibular schwannomas. Neurosurgery 2009; 64: 48-55.

33. Chung WY, Pan DH, Lee CC, et al. Large vestibular schwannomas treated by Gamma Knife surgery: long-term outcomes. I Neurosurg 2010; 113: 112-21.

34. Gerosa M, Mesiano N, Longhi M, De Simone A, Foroni R, Verlic chi A, Zanotti B, Nicolato A. Gamma Knife surgery in vestibular schwannomas: impact on the anterior and posterior labyrinth. J Neurosurg 2010; 113: 128-35.

35. Kano H, Kondziolka D, Niranjan A, Flannery TJ, Flickinger JC, Lunsford LD. Repeat stereotactic radiosurgery for acoustic neuromas. Int J Radiation Oncology Biol Phys 2010; 76: 520-7.

36. Lee CC, Yen YS, Pan DH, et al. Delayed microsurgery for vestibular schwannoma after Gamma Knife radiosurgery. J Neurooncol 2010; 98: 203-12.

37. Nagano O, Serizawa T, Higuchi Y, et al. Tumor shrinkage of vestibular schwannomas after Gamma Knife surgery: results after more than 5 years of follow-up. J Neurosurg 2010; 113: 122-7.

38. Nakaya K, Niranjan A, Kondziolka D, et al. Gamma Knife radiosurgery for benign tumors with symptoms from brainstem compression. Int J Radiation Oncology Biol Phys 2010; 77: 988-95.

39. Régis J, Carron R, Park MC, Soumare O, Delsanti C, Thomassin JM, Roche $\mathrm{PH}$. et al. Wait-and-see strategy compared with proactive Gamma Knife surgery in patients with intracanalicular vestibular schwannomas. J Neurosurg 2010; 113: 105-11.

40. Sharma MS, Singh R, Kale SS, Agrawal D, Sharma BS, Mahapatra AK. Tumor control and hearing preservation after Gamma Knife radiosurgery for vestibular schwannomas in neurofibromatosis type 2. J Neurooncol 2010; 98: 265-70.

41. Timmer FC, van Haren AE, Mulder JJ, Hanssens PE, van Overbeeke JJ, Cremers CW, Graamans K. Quality of life after Gamma Knife radiosurgery treatment in patients with a vestibular schwannoma: the patient's perspective. Eur Arch Otorhinolaryngol 2010; 267: 867-73.

42. Yomo S, Tamura M, Carron R, Porcheron D, Régis J. A quantitative comparison of radiosurgical treatment parameters in vestibular schwannomas: the Leksell Gamma Knife Perfexion versus Model 4C. Acta Neurochir 2010; 152: 47-55.

43. Brown M, Ruckenstein M, Bigelow D, Judy K, Wilson V, Alonso-Bas anta M, Lee JY. Predictors of hearing loss after Gamma Knife ra diosurgery for vestibular schwannomas: age, cochlear dose, and tumor coverage. Neurosurgery 2011; 69: 605-14.

44. Haque R, Wojtasiewicz TJ, Gigante PR, Attiah MA, Huang B, Isaac son SR, Sisti MB. Efficacy of facial nerve-sparing approach in patients with vestibular schwannomas. J Neurosurg 2011; 115: 917-23.

45. Hasegawa T, Kida Y, Kato T, lizuka H, Yamamoto T. Factors associated with hearing preservation after Gamma Knife surgery for vestibular schwannomas in patients who retain serviceable hearing. J Neurosurg 2011; 115: 1078-86.

46. van de Langenberg R, Hanssens PE J, van Overbeeke JJ, Verheul JB, Nelemans PJ, de Bondt BJ, et al. Management of large vestibular schwannoma. Part I. Planned subtotal resection followed by Gamma Knife surgery: radiological and clinical aspects. J Neurosurg 2011; 115: 875-84.

47. van de Langenberg R, Hanssens PE, Verheul JB, van Overbeeke JJ, Nelemans PJ, Dohmen AJ, de Bondt BJ, Stokroos RJ. Management of large vestibular schwannoma. Part II. Primary Gamma Knife surgery: radiological and clinical aspects. J Neurosurg 2011; 115: 885-93.

48. Massager N, Lonneville S, Delbrouck C, Benmebarek N, Desmedt F, Devriendt D. Dosimetric and clinical analysis of spatial distribution of the radiation dose in Gamma Knife radiosurgery for vestibular schwannoma. Int J Radiation Oncology Biol Phys 2011; 81: 511-8.

49. Milligan BD, Pollock BE, Foote RL, Link MJ. Long-term tumor control and cranial nerve outcomes following Gamma Knife surgery for larger-volume vestibular schwannomas. J Neurosurg 2012; 116: 598-604.

50. Murphy ES, Barnett GH, Vogelbaum MA, Neyman G, Stevens GHJ, Cohen $\mathrm{BH}$, et al: Long-term outcomes of Gamma Knife radiosurgery in patiens with vestibular schwannomas. J Neurosurg 2011; 114: 432-40.

51. Park CE, Park BJ, Lim YJ, Yeo SG. Functional outcomes in retrosigmoid approach microsurgery and Gamma Knife stereotactic ra- diosurgery in vestibular schwannoma. Eur Otorhinolaryngol 2011; 268: 955-9.

52. Yang HC, Kano H, Awan NR, et al. Gamma Knife radiosurgery for larger-volume vestibular schwannomas. J Neurosurg 2011; 114: 801-7.

53. Akamatsu Y, Sugawara T, Mikawa S, Saito A, Ono S, Takayama K, Jokura H, Seki H. Ruptured pseudoaneurysm following Gamma Knife surgery for a vestibular schwannoma. J Neurosurg 2009; 110: 543-6.

54. Franco-Vidal V, Songu M, Blanchet H, Barreau X, Darrauzt V. Intracochlear hemorrhage after gamma knife radiosurgery. Otol Neurotol 2007; 28: 240-4.

55. Karampelas I, Alberico RA, Plunkett RJ, Fenstermaker RA: Intratumoral hemorrhage after remote subtotal microsurgical resection and Gamma Knife radiosurgery for vestibular schwannoma. Acta Neurochir (Wien) 2007; 149: 313-7.

56. Neuhaus O, Saleh A, van Oosterhout A, Siebler M. Cerebellar in farction after gamma knife radiosurgery of a vestibular schwannoma. Neurology 2007; 68: 590.

57. Park KY, Ahn JY, Lee JW, Chang JH, Huh SK. De novo intracranial aneurysm formation after Gamma Knife radiosurgery for vestibular schwannoma. J Neurosurg 2009; 110: 540-2.

58. Vachhrajani S, Fawaz C, Mathieu D, et al. Complications of Gamma Knife surgery: an early report from 2 Canadian centers. J Neurosurg 2008; 109: 2-7.

59. Myrseth E, Pedersen PH, M ller P, Lund-Johansen M. Treatment of vestibular schwannomas. Why, when and how ? Acta Neurochir (Wien) 2007; 149: 647-60.

60. Rowe J, Grainger A, Walton L, Silcocks P, Radatz M, Kemeny A. Risk of malignancy after Gamma Knife stereotactic radiosurgery. Neurosurgery 2007; 60: 60-6.

61. Sughrue ME, Yang I, Han SJ, Aranda D, Kane AJ, Amoils M, Smith ZA, Parsa AT. Non-audiofacial morbidity after Gamma Knife surgery for vestibular schwannoma. Neurosurg Focus 2009; 27: E4.

62. Yang I, Sughrue ME, Han SJ, Fang S, Aranda D, Cheung SW, Pitts LH, Parsa AT. Facial nerve preservation after vestibular schwannoma Gamma Knife radiosurgery. J Neurooncol 2009; 93: 41-8.

63. Yang I, Aranda D, Han SJ, Chennupati S, Sughrue ME, Cheung SW, Pitts LH, Parsa AT. Hearing preservation after stereotactic radiosurgery for vestibular schwannoma: a systematic review. J Clin Neurosci 2009; 16: 742-7.

64. Yang I, Sughrue ME, Han SJ, Aranda D, Pitts LH, Cheung SW, Parsa AT. A comprehensive analysis of hearing preservation after radiosurgery for vestibular schwannoma. J Neurosurg 2010; 112: 851-9.

65. Murphy ES, Suh JH. Radiotherapy for vestibular schwannomas: a critical review. Int J Radiation Oncology Biol Phys 2011; 79: $985-$ 97.

66. Whitmore RG, Urban C, Church E, Ruckenstein M, Stein SC, Lee JY. Decision analysis of treatment options for vestibular schwannoma. J Neurosurg 2011; 114: 400-13.

\section{Address for correspondence}

\section{Bartosz Rykaczewski}

Mazovia Regional Hospital

Kondratowicza 8

02-797 Warsaw

e-mail: bartosz.rykaczewski@gmail.com

Submitted: 9.01 .2013

Accepted: 20.02 .2013 